\title{
Caracterização hidrossedimentológica dos trechos aluviais da bacia Riacho do Tigre
}

\author{
Hidrossedimentology characterization of alluvial reaches \\ in the tigre creek watershed
}

\begin{abstract}
Adonai Felipe Pereira de Lima SILVA ${ }^{1}$
Jonas Otaviano Praça de SOUZA2
\end{abstract}

\begin{abstract}
RESUMO
As pesquisas voltadas à gestão dos recursos hídricos vêm ganhando importância nos últimos anos no Brasil, sobretudo no nordeste, em decorrência dos anos de estiagem prolongada em ambientes semiáridos. Contudo, a exploração dos aquíferos aluviais surge como alternativa complementar para suprir a carência hídrica, buscando aperfeiçoar as formas de captação, armazenamento e uso de água pelas comunidades. Assim, este trabalho buscou identificar e caracterizar os trechos fluviais com possibilidade de presença de aquíferos aluviais, de modo que a comunidade local possa melhorar as técnicas de captação, uso e armazenamento de água através da exploração desses ambientes. A pesquisa foi realizada no município de São João do Tigre - PB. Foram realizados os mapeamentos dos trechos aluviais, fazendo a identificação do uso e ocupação do solo. Os trechos aluviais passaram por análises e classificações sedimentológicas, e posteriormente fazendo-se o agrupamento de três classes referente aos tipos de depósitos aluviais. A partir dos resultados gerados foi possível concluir que as áreas de estocagem de deposição estão concentradas nos ambientes de baixo gradiente. A alta hidrodinâmica apresentada nos resultados reflete na alta variação dos tipos de depósitos aluviais analisados, podendo gerar influência na formação de aquíferos aluviais com características diversas.

Palavras-chave: Aquíferos aluviais; Ambientes fluviais semiáridos; Gestão da água.
\end{abstract}

\begin{abstract}
The research focused on the management of water resources are gaining importance in recent years in Brazil, especially in the Northeast, due to the years of prolonged drought in semiarid environments. However, exploitation of alluvial aquifers appears as alternative complement to supply the water shortage, seeking to improve the forms of capture, storage and use of water by communities. Thus, this study sought to identify and characterize the river stretches in which there is the possibility of alluvial aquifers, so that the local community can improve harvesting techniques of water use and storage by exploiting these environments. The survey was
\end{abstract}

\footnotetext{
1 Universidade Federal da Paraíba, João Pessoa, PB, Brasil. ad.felipelima@hotmail.com

2 Professor Adjunto, Centro de Ciências Exatas e da Natureza, Departamento de Geociências, niversidade Federal da Paraíba, João Pessoa, PB, Brasil. jonasgeoufpe@yahoo.com.br
} 
conducted in the municipality of São João do Tigre - PB. The mapping of alluvial sections were performed, making the identification of land use and occupation. Sedimentological analysis and ratings were made to the alluvial stretches, and then making up the grouping of three classes referring to the types of alluvial deposits. From the generated results it was concluded that the deposition of storage areas are concentrated in low-gradient environments. The high hydrodynamics presented in the results reflects in the high variation of the analyzed types of alluvial deposits, which can generate influence in the formation of alluvial aquifers with different characteristics.

Keywords: Aquifers Alluvial; Semiarid riverine environments; Water management.

$$
* * *
$$

\section{Introdução}

Antigas civilizações afloraram nas margens dos grandes rios, algumas se desenvolveram dessa maneira até os dias atuais, pois os rios além de serem importantes agentes geológicos como responsáveis pela ação modeladora do relevo, também são extremamente importantes para a vida e sobrevivência do homem (BIGARELLA, SUGUIO e BECKER, 1979).

As bacias hidrográficas têm se configurado como unidade de gestão e planejamento ambiental, devendo ser analisadas a partir da perspectiva de um recorte espacial sistêmico. Uma ideia mais ampla sobre bacias como unidade de planejamento/gestão atinge um alcance além dos processos hidrológicos, considerando os aspectos da estrutura biofísica, a análise das modificações nos padrões de uso da terra e suas implicações no meio ambiente. (PIRES, SANTOS e DEL PRETTE, 2008).

Os estudos sobre ambientes fluviais nas bacias hidrográficas da América do Sul são aplicados na grande maioria em regiões onde prevalece o clima úmido. Diante desse fato, é preciso haver precauções ao fazer análises dos sistemas fluviais em terras secas, pois estas requerem uma abordagem diferenciada, visto que nesta região os processos fluviais ocorrem de maneira mais rápida e intensa (CAVALCANTE e CUNHA, 2012). Seguindo esse pensamento, Souza e Almeida (2015) complementam afirmando que:

Os processos em ambientes semiáridos e em ambientes sub-úmidos apresentam características processuais diferenciadas em relação aos 
ambientes úmidos. Essa diferenciação é resultado da diferença dos inputs de energia no sistema, em específico da precipitação. Por conseguinte, a diferenciação processual vai resultar em uma diferenciação das formas e estruturas do sistema (SOUZA e ALMEIDA, 2015, p. 111).

A ideia de otimizar o gerenciamento de recursos hídricos está cada vez mais presente nas políticas públicas, no entanto, é possível perceber que na maioria das vezes as aplicabilidades das práticas de planejamento estão focadas no elemento água, deixando de lado outros elementos físicos da bacia hidrográfica. O desafio da gestão da água torna-se mais complexo quando se trata de um ambiente fluvial semiárido, devido à escassez de chuva, à ausência de cursos perenes de água, além da insuficiência de disponibilidade hídrica nos reservatórios durante maior parte do ano (SOUZA e ALMEIDA, 2015).

No semiárido, as características climáticas e geológicas têm representado um desafio referente ao aproveitamento dos recursos hídricos, levando em consideração o baixo índice de pluviosidade e a má distribuição espacial/temporal das precipitações, além da composição da estrutura geológica regional que se apresenta desfavorável à retenção de grandes volumes de água oriundas da precipitação. Outro problema são as altas taxas de evaporação que geralmente são superiores às taxas de precipitação, podendo acelerar o processo de salinização, ocasionando perda de volume de água e reduzindo a eficiência dos reservatórios (SCHUSTER et al, 2004).

Assim, pensando em abordagens que tenham como objetivo aperfeiçoar a captação, armazenamento e uso dos recursos hídricos pelas comunidades, surgem algumas alternativas com o intuito de complementar o suprimento de água no semiárido nos períodos de estiagem, como a exploração dos aquíferos aluviais. Os depósitos aluviais são reservas hídricas capazes de armazenar expressivos volumes de água. São formados por sedimentos clásticos (cascalhos, areias e finos) depositados nas margens e nos leitos das drenagens através dos processos dinâmicos ocorridos em um sistema fluvial (SÁ e DINIZ, 2012). Esses reservatórios hídricos são sustentáveis apenas enquanto 
puderem oferecer espaço de armazenamento de água suficiente para executar sua função (GRAF, 2010).

Os estudos sobre aquíferos aluviais e depósitos aluviais são de grande importância no contexto do semiárido brasileiro, pois além de se tratar de um espaço com déficit hídrico, os aquíferos aluviais são mais favoráveis às recargas oriundas da precipitação e são fáceis de escavar ou perfurar, tornando sua exploração simples e de baixo custo, podendo possibilitar um melhor desenvolvimento socioeconômico na região através da agricultura de pequena escala (SANTOS, FREIRE e SOUZA, 2009; SÁ e DINIZ, 2012). Levando em consideração a sustentabilidade hídrica, é notável que a exploração dos aquíferos aluviais torna-se mais viável em relação aos aquíferos cristalinos. As escavações podem ser simples, manuais, sem revestimento ou escavações como a construção de poços amazonas; a escavação de poços amazonas geralmente apresenta média entre 3 a 5 metros de profundidade, onde se faz os anéis de concreto (ou tijolos) um por vez.

Algumas situações podem comprometer a potencialidade dos aquíferos aluviais, por exemplo, quando a retirada de água é maior que a capacidade de recarga (ALBUQUERQUE et al, 2015), a má locação dos poços que são realizadas sem o conhecimento prévio das características locais do aquífero, como espessura, dimensões e litologia (SÁ e DINIZ, 2012) e a escavação generalizada de cacimbas nos rios, alterando a forma do leito e consequentemente possibilitando variações de direção e velocidade do fluxo na margem erosiva, causando ou agravando a erosão das margens (SOUZA e

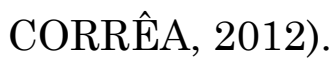

Nesse sentido, considerando as múltiplas situações que podem comprometer a potencialidade dos aquíferos aluviais, Fontes Júnior et al. (2012) enaltecem a importância do monitoramento dos aluviões ao discutir sobre a disponibilidade hídrica em ambientes fluviais semiáridos:

Os recursos hídricos subterrâneos aluviais são estratégicos paras as populações rurais no semiárido brasileiro. As restrições no uso e na disponibilidade das águas subterrâneas nos aluviões estão diretamente ligadas à sazonalidade e à variabilidade espacial de seus níveis e 
salinidade, requerendo monitoramento sistemático de sua quantidade e qualidade (FONTES JÚNIOR et al, 2012, pág. 1189).

Dentre os impactos ambientais nos aluviões as barragens talvez sejam o de maior expressão em terras secas. As barragens superficiais podem favorecer a inundação de algumas áreas que normalmente não sofrem inundação, aumentar a profundidade dos aquíferos ou ainda provocar alterações no regime do fluxo. Além disso, o processo de sedimentação a jusante da barragem pode ser drasticamente reduzido. (LOVE et al, 2011; SOUZA e ALMEIDA, 2015).

Nessa perspectiva, o presente trabalho visa realizar a identificação e caracterização sedimentológica dos trechos fluviais, de modo que haja a possibilidade de presença de aquíferos aluviais, visando um melhor entendimento dessas áreas, gerando informações úteis para que a população residente possa melhorar as práticas e técnicas de aperfeiçoamento de captação, uso e armazenamento dos recursos hídricos através da exploração desses ambientes. A pesquisa foi realizada na bacia riacho do Tigre, no município de São João do Tigre, semiárido paraibano.

\section{Caracterização da área}

As pesquisas foram realizadas na bacia hidrográfica riacho do Tigre, localizada no município de São João do Tigre-PB (figura 1). O município de São João do Tigre está completamente inserido na unidade de relevo do Planalto da Borborema. Em relação à compartimentação megageomorfológica do Planalto da Borborema, a parte mais elevada de São João do Tigre está situada na zona dos Maciços Remobilizados do Domínio da Zona Transversal, enquanto que a parte baixa está na depressão intraplanáltica paraibana. Essas áreas apresentam evidências de ciclos de erosão que atingiram grande parte do sertão nordestino. O controle estrutural da área influencia em outros elementos, como: os rios, que não avançam além da escarpa oriental que delimita o planalto; e o clima, reduzindo o grau de temperatura na medida em 
que superfície se encontra mais alta, causando também a diferenciação de temperatura de vertentes a barlavento e a sotavento. A influência da estrutura geológica se deve às rochas cristalinas, que são mais resistentes à erosão em relação aos outros tipos de rochas de áreas adjacentes, configurando o relevo ondulado da Borborema (CORRÊEA et al, 2010).

Figura 1: Mapa de Localização da Bacia do Riacho do Tigre

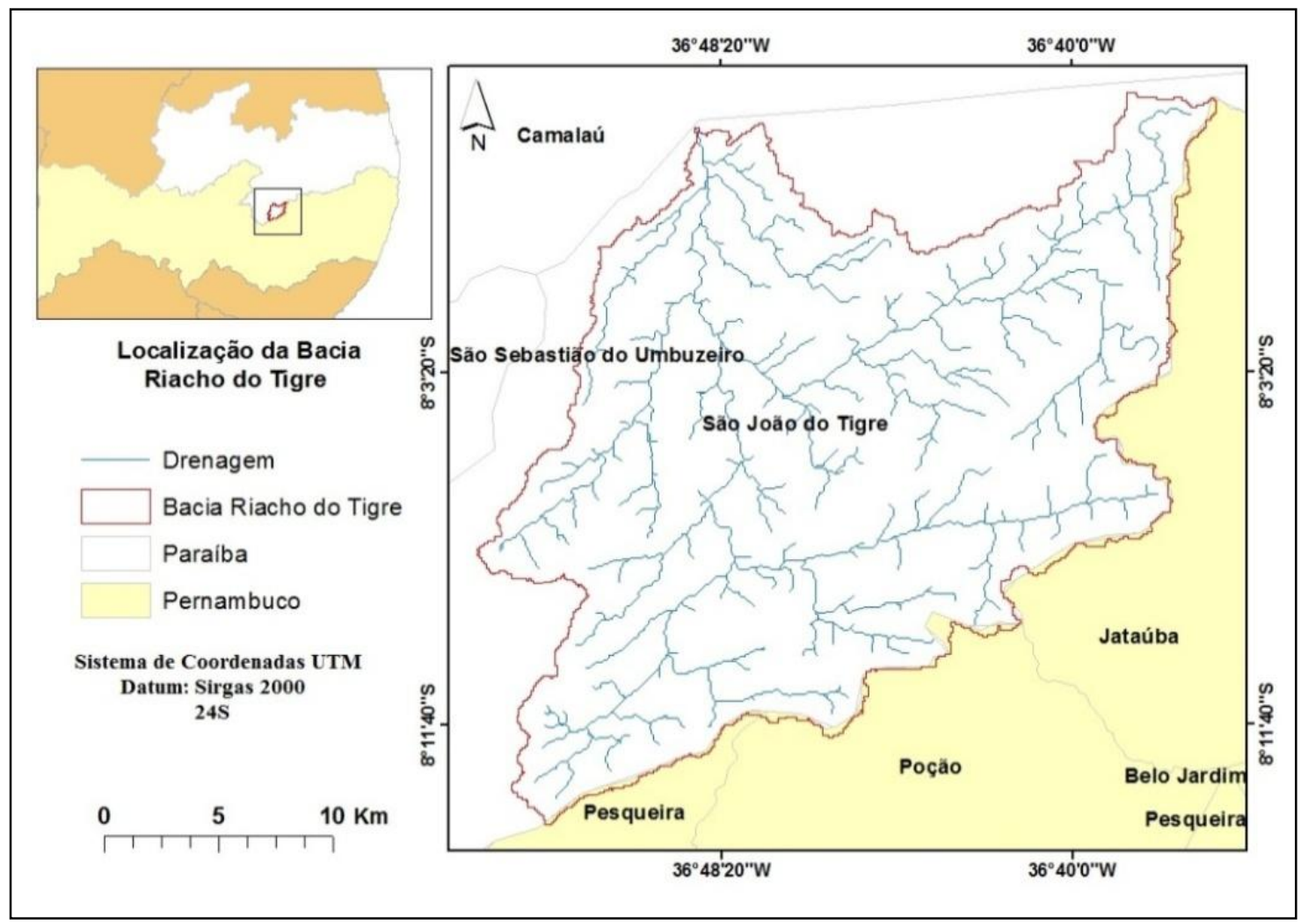

Fonte: Os autores

Os rios da bacia são intermitentes, típicos de ambientes semiáridos com vazão ausente durante maior parte do ano, tendo em média menos de 40 dias de fluxo por ano. Contudo não há dados observados, sendo que essa é a média padrão para canais de ordem semelhante na região. O bioma é a caatinga, apresentando como vegetação predominante a Caatinga hiperxerófila com presença de alguns trechos de floresta caducifólia. O clima é Tropical semiárido, com chuvas de verão nos períodos entre novembro e abril e apresentando pluviosidade média anual de 431,8mm (IBGE, 2016). 
Os tipos de solos podem variar de acordo com a declividade e a posição no relevo: os Planossolos são predominantes nas áreas de relevo plano e suave ondulado nas proximidades dos canais, esses solos são mal drenados, possuem fertilidade natural média e alto teor de sais; os Luvissolos Crômicos estão presentes nas médias vertentes com declividades medianas, são solos rasos e de alta fertilidade natural; os Argissolos estão no topo e em altas vertentes do relevo ondulado, esse tipo de solo apresenta fertilidade natural média; e os Neossolos Litólicos - solos rasos, pedregosos e de fertilidade natural média estão presentes nas áreas com alta declividade (CPRM, 2005).

\section{Materiais e métodos}

Os procedimentos metodológicos que foram adotados nessa pesquisa tiveram como foco identificar e caracterizar os diferentes trechos aluviais da bacia riacho do Tigre quanto à sua dinâmica hidrológica e sedimentológica, para isso buscou-se realizar: a identificação e mapeamento dos diferentes trechos aluviais da bacia riacho do Tigre; caracterização sedimentológica dos trechos aluviais em relação à hidrodinâmica; identificação de uso e dos impactos antrópicos nos trechos aluviais; e a tipificação dos trechos aluviais da bacia.

Os dados necessários para o desenvolvimento da pesquisa foram obtidos através da literatura, dados de altitude do SRTM (Shuttle Radar Topography Mission, imagens de satélite e por fim os dados do trabalho de campo. Inicialmente foram realizados dois trabalhos de campo exploratórios, com os pontos de visita definidos por análise prévia de imagens de satélite, e tendo como objetivo identificar as características ambientais da bacia, a diferença entre os ambientes fluviais e escolher os pontos que foram analisados. Os dados exploratórios de campo foram adquiridos através dos do uso do GPS, trena, estação total. Após a escolha dos pontos de análise houve mais dois trabalhos de campo, onde foram obtidas as informações necessárias para o mapeamento e coleta das amostras para serem analisadas em laboratório, além da confirmação da interpretação das imagens do 
sensoriamento remoto, questionamentos à comunidade referentes ao uso da terra e realização dos procedimentos quanto ao perfil lateral e longitudinal. As informações para a construção do perfil lateral e o cálculo do gradiente de cada canal analisado foram obtidos através das medições topográficas realizadas pelo uso da estação total e trena.

A identificação e mapeamento dos diferentes trechos aluviais da bacia foram realizados através de uma caracterização geral dos trechos analisados, com ênfase na identificação de cada um deles, buscando identificar a localização, cobertura, geometria, largura do vale e sua variação. As análises foram feitas através de sensoriamento remoto, além do mapeamento de campo usando GPS, trena e estação total. A localização dos trechos, assim como as margens e o leito das drenagens foram identificadas com precisão com o auxílio do GPS. As informações referentes à geometria do canal e a largura do vale e sua variação foram adquiridas através da estação total e desenvolvidas com o auxílio das ferramentas do sensoriamento remoto e dos sistemas de informações geográficas, com a utilização do software ArcGis 10.2.2. No ArcGis foi possível obter resultado do cálculo do fluxo acumulado usando as ferramentas flow direct e flow acumulation. A Geometria foi determinada conforme os parâmetros de Fryirs e Brierley (2012).

Para caracterizar os trechos aluviais quanto sua dinâmica sedimentológica e hidrológica foi necessário fazer a coleta e caracterização sedimentológica da área em questão. Primeiramente procurou-se identificar as áreas para a coleta das amostras, onde foram cavadas trincheiras superficiais visando à análise de perfis estratigráficos e das propriedades sedimentológicas na qual foram examinadas posteriormente em laboratório. Sendo assim, as análises tiveram como objetivo a caracterização quantitativa e qualitativa dos sedimentos, sendo a base para a preparação das análises granulométrica e morfoscópica. As avaliações granulométricas e morfoscópica foram realizadas buscando compreender a hidrodinâmica nos trechos analisados, o retrabalhamento do material transportado, a turbulência do fluxo e as causas da deposição. 
A granulometria das areias e dos cascalhos foi realizada através do peneiramento das amostras, onde as frações de silte e argila foram dispensadas. Partes das informações obtidas foram baseadas na proposta metodológica de Gale \& Hoare (1991). Para a separação dos sedimentos mais finos o método adotado foi o da pipetagem, com base nas recomendações de Gale \& Hoare (1991). No entanto, a pipetagem neste trabalho foi executada buscando apenas a separação das partículas de argila, avaliando a porcentagem de silte por proporção. Os valores obtidos das frações granulométricas foram submetidos aos parâmetros estatísticos propostos por Folk \& Ward (1957); a classificação dos sedimentos foi realizada usando o diagrama de Shepard (1954) e Pejrup (1988) através do programa Sysgran 3.0.

A morfoscopia foi realizada seguindo os parâmetros metodológicos de Tucker (1995), visando à avaliação qualitativa e quantitativa do material, servindo de base para compreensão dos processos dinâmicos deposicionais.

A identificação dos usos e impactos antrópicos nos trechos aluviais foi efetuada a através da observação de imagens orbitais da área, das considerações percebidas no trabalho de campo e a partir do contato com as comunidades, buscando avaliar os tipos e periodicidades das intervenções humanas. Além disso, foi realizado o mapeamento detalhado dos trechos aluviais, usando o software ArcGis 10.2.2, podendo ser acrescentadas além das características naturais as formas de construção antrópica - como, por exemplo, as estradas, cercas, poços, barragens e casas - como também as áreas de exploração da comunidade (agricultura e pecuária).

A tipificação dos trechos aluviais da bacia foi realizada na tentativa de criar e estabelecer uma tipologia de tipos de depósitos aluviais. A execução desse procedimento tem como base a utilização dos dados obtidos na caracterização sedimentológica (análises granulométricas e morfoscópicas), dados topográficos e dados do uso e ocupação do solo. Dessa forma, os depósitos aluviais foram categorizados de acordo com sua dinâmica deposicional e os tipos de sedimentos depositados. 


\section{Resultados}

Após as análises de diversos trechos fluviais da bacia riacho do Tigre observadas por imagens de satélite e no trabalho do campo - foram selecionados oito trechos a partir de suas diferenças naturais e de localização (figura 2), sendo quatro no canal principal da bacia (riacho do Tigre) e quatro nas mediações dos dois principais afluentes, que é o riacho Santa Maria e o riacho Cacimbinha, onde os trechos 5 e 7 estão situados em canais de ordem inferior.

Figura 2 Modelo Digital de Elevação e localização dos trechos trabalhados

\section{Legenda \\ A Trechos \\ $\sim$ Drenagem \\ Riacho Santa Maria \\ - Riacho do Tigre \\ n Riacho Cacimbinha \\ 3 Bacia riacho do Tigre}

\section{Altitude}

Metros

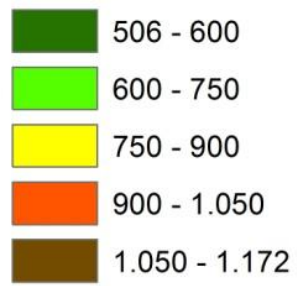

Sistema de coordenada UTM Datum SIRGAS 2000 ZONA 24S

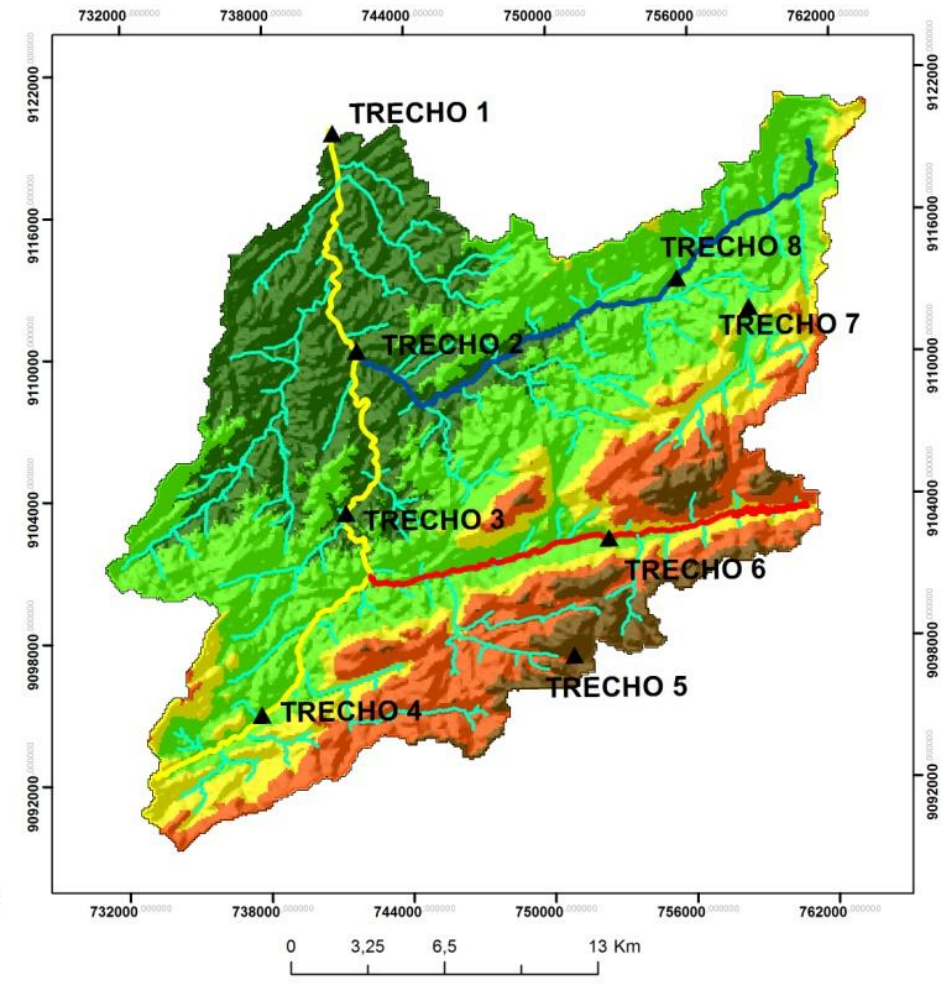

Fonte: Os autores

Os trechos foram selecionados em localizações distintas na bacia, onde cada trecho apresenta características diferentes (altitude, declividade, cobertura vegetal, intensidade de influência antrópica, tipos de vales, dinâmica fluvial etc.), de modo que pudesse representar a dinâmica fluvial da bacia Riacho do Tigre integralmente (figura 3). 
A amplitude altimétrica entre o início e a foz dos três principais riachos revelam características diferentes. O riacho do Tigre é o mais extenso, com altitudes variando entre $500 \mathrm{~m}$ a quase $800 \mathrm{~m}$ e com extensão de aproximadamente $40.000 \mathrm{~m}$; o riacho Cacimbinha é o que apresenta o segundo maior valor de extensão $(32.000 \mathrm{~m})$ e abrange o menor valor de altitude em comparação com os demais, com variações de altitude entre 550 m e 750 m; e por último o riacho de Santa Maria, o que apresenta menor extensão em relação aos outros dois já citados $(21.000 \mathrm{~m})$, além de ser o riacho que abrange os maiores valores de altitude, com variações altimétricas entre $600 \mathrm{~m}$ e $950 \mathrm{~m}$.

Após a realização das análises sedimentológicas de todos esses trechos, foi gerado um agrupamento de classes de três tipos de depósitos sedimentares: depósitos com maior proporção de sedimento fino (em relação aos demais da bacia); depósitos com maior proporção de sedimento grosso; e depósitos de vale preenchido. Os possíveis mecanismos de deposição dos sedimentos possivelmente estão relacionados ao baixo gradiente, contrição do vale, depressões isoladas no leito, barramentos etc. A seguir, os trechos serão apresentados acompanhando a ordem dos tipos de depósitos sedimentares.

A figura 3 representa as fotografias dos canais na perspectiva da direção do fluxo a jusante no horizonte, exceto na ilustração (B) que corresponde a uma planície de inundação em uma área de confluência. A primeira ilustração, denominada por (A) é o trecho 1; ao lado da primeira, (B) é o trecho 2; na sequência, (C) é o trecho 3; (D) é o trecho 4; (E) é o trecho 5; (F) é o trecho 6; (G) é o trecho 7; e por fim, a ilustração $(\mathrm{H})$ representa o trecho 8 . 
Figura 3. Fotografias dos oito trechos.
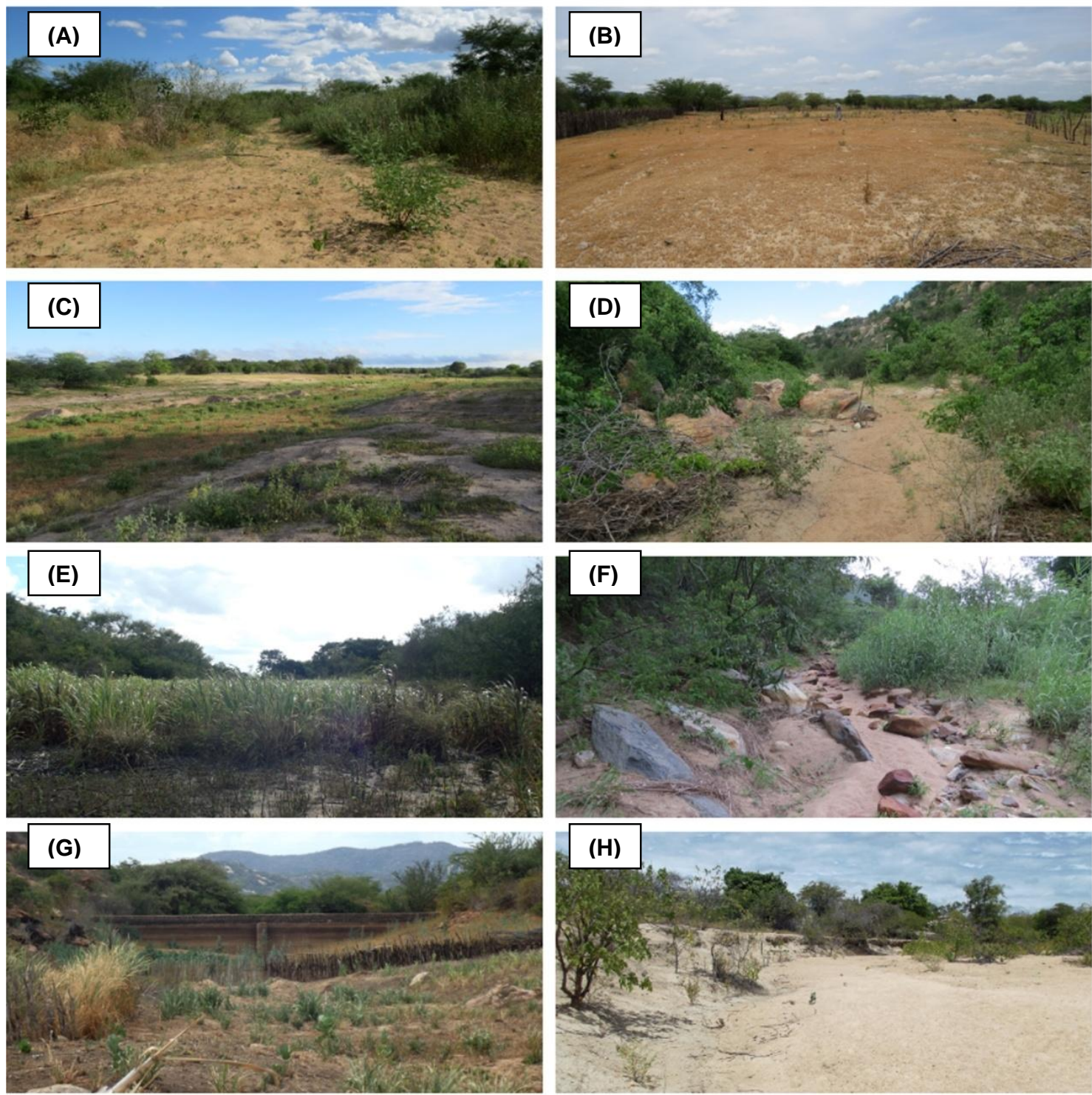

Fonte: Os autores.

Os trechos 1 e 2 foram inseridos na classe dos depósitos sedimentares com maiores proporções de sedimentos finos, além do baixo gradiente. $\mathrm{O}$ trecho 1 situa-se na foz da bacia, corresponde a um canal arenoso entrelaçado com presença de algumas barras arenosas e planície de inundação (figura 4). A partir das análises realizadas em trabalho de campo, sobre a vegetação é possível perceber a presença de poucas arbóreas, arbustivas com cobertura intermediária e herbáceas com cobertura densa, com predominância de vegetação arbustiva. Também há espaços com solo exposto ao redor do canal 
e vegetação arbustiva no leito. O mapeamento da área foi realizado, e a partir deste fazer a identificação da geometria do canal, calcular o fluxo acumulado da área e a largura do vale. A área sofre influência antrópica da agricultura a aproximadamente 150 metros ao lado da margem direita. O canal é largo, com presença de algumas barras arenosas com planície de inundação dos dois lados.

Figura 4: Mapa de uso e ocupação do Trecho 1.

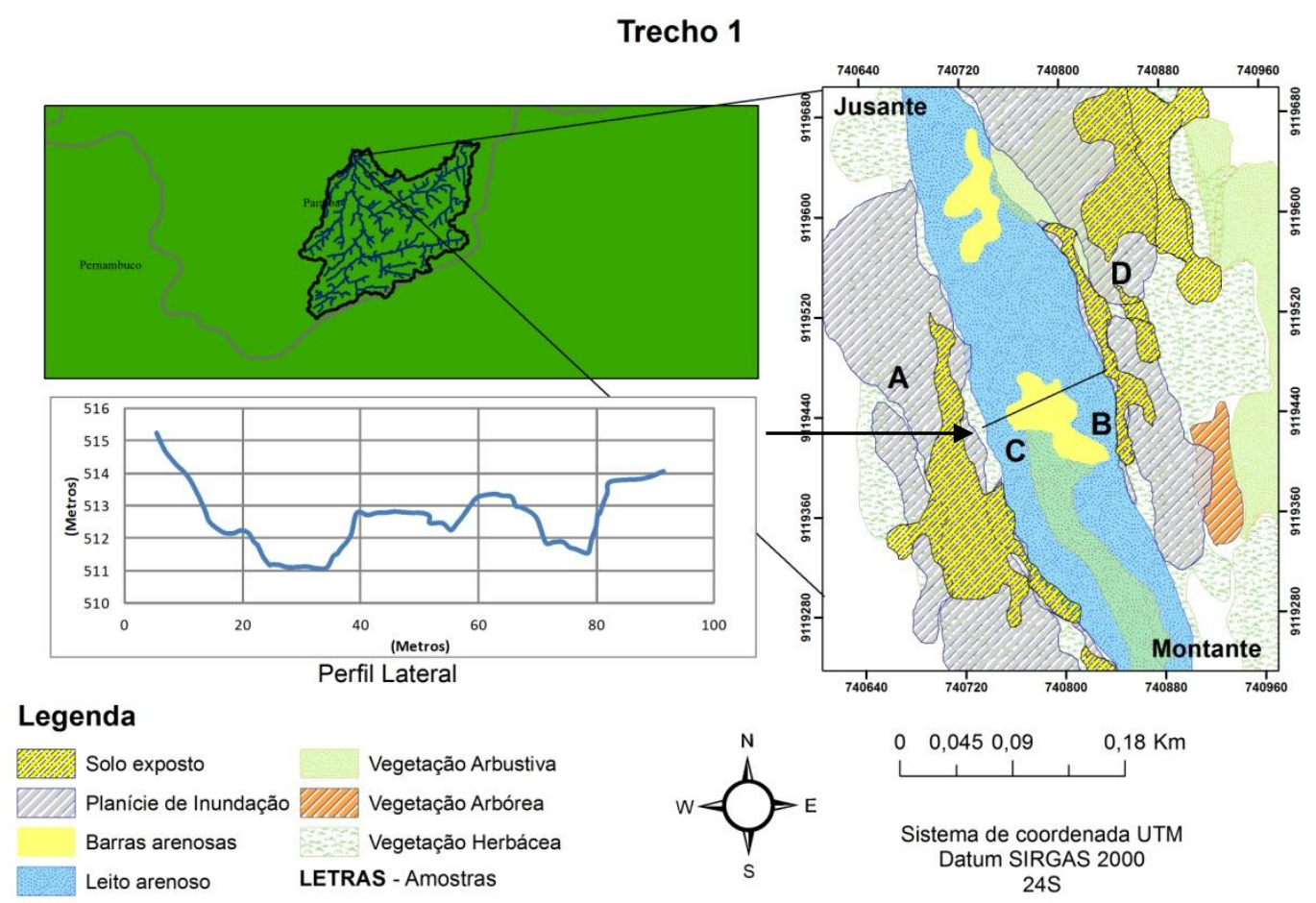

Fonte: Os autores

O gradiente é de $1,1 \mathrm{~m} / \mathrm{km}$, configurando-se em uma área com baixa/média energia e competência de fluxo. A partir do mapeamento do trecho foi possível obter informações adicionais, como: a largura do canal, equivalente a $89 \mathrm{~m}$; a geometria é irregular; e a área de captação de $531,3 \mathrm{~km}^{2}$. De acordo com os dados do gradiente - relativamente baixo - e a largura do canal - relativamente alta - estima-se que a energia do fluxo é baixa, favorecendo o processo de sedimentação. O cálculo do fluxo acumulado mostra que o trecho abrange uma extensa área de captação e, consequentemente, recebe uma quantidade maior de sedimentos. De modo geral, a classificação 
dos sedimentos apresenta predominância de areia (tabela 1). A amostra D é a única do trecho 1 em que as frações das amostras não são compostas majoritariamente de areia, havendo $43 \%$ de silte e $43 \%$ de areia; já as amostras restantes predominam as frações de areia. Os diagramas revelaram que a sedimentação se deu através de um fluxo turbulento. A concentração de areia nas amostras do canal (B e C) deve-se à energia do fluxo que é maior em relação ao fluxo que atuou no processo de deposição das planícies. O fluxo com maior energia do canal é capaz de transportar com mais facilidade os sedimentos mais finos como silte a argila, refletindo também esse processo na seleção dos grãos, sendo no canal é mais selecionado, indicando que o comportamento do fluxo é mais homogêneo. Nas planícies o fluxo pode sofrer variação de turbulência, gerando depósitos mal selecionados.

Tabela 1. Dados de granulometria e morfoscopia das amostras do trecho 1.

\begin{tabular}{|c|c|c|c|c|}
\hline Amostras & \multicolumn{2}{|c|}{ Classificação dos sedimentos } & \multicolumn{2}{|c|}{ Grau de seleção } \\
\hline $\mathrm{A}$ & \multicolumn{2}{|c|}{ Areia muito fina } & \multicolumn{2}{|c|}{ Muito pobremente selecionado } \\
\hline $\mathrm{B}$ & \multicolumn{2}{|c|}{ Areia muito grossa } & \multicolumn{2}{|c|}{ Moderadamente selecionado } \\
\hline C & \multicolumn{2}{|c|}{ Areia muito grossa } & \multicolumn{2}{|c|}{ Moderadamente selecionado } \\
\hline $\mathrm{D}$ & \multicolumn{2}{|c|}{ Silte grosso } & \multicolumn{2}{|c|}{ Muito pobremente selecionado } \\
\hline \multicolumn{2}{|c|}{ Amostras - Morfoscopia } & Arredondamento & Esfericidade & Brilho \\
\hline \multicolumn{2}{|c|}{$\mathrm{A}$} & Angular & Esférico & Opaco \\
\hline \multicolumn{2}{|c|}{$\mathrm{B}$} & Sub Angular & Sub Discoidal & Opaco \\
\hline \multicolumn{2}{|c|}{ C } & Sub Angular & Sub Discoidal & Opaco \\
\hline \multicolumn{2}{|c|}{$\mathrm{D}$} & Muito Angular & Sub Prismoidal & Transparente \\
\hline Amostras & \multicolumn{2}{|c|}{ Diagrama de Shepard } & \multicolumn{2}{|c|}{ Diagrama de Pejrup } \\
\hline $\mathrm{A}$ & \multicolumn{2}{|c|}{ Areia síltica } & \multicolumn{2}{|c|}{ No limite entre alta e muito alta } \\
\hline $\mathrm{B}$ & \multicolumn{2}{|c|}{ Areia } & \multicolumn{2}{|c|}{ Muito alta } \\
\hline C & \multicolumn{2}{|c|}{ Areia } & \multicolumn{2}{|c|}{ Muito alta } \\
\hline $\mathrm{D}$ & \multicolumn{2}{|c|}{ No limite entre areia síltica e silte arenoso } & \multicolumn{2}{|c|}{ No limite entre alta e muito alta } \\
\hline
\end{tabular}

O trecho 2 está localizado no canal principal da bacia, alguns quilômetros a montante do trecho 1, correspondendo a confluência entre o riacho do Tigre (canal principal) e o riacho Cacimbinha (figura 5). A paisagem demonstra ser uma área com bastante intervenção humana, sendo as planícies de inundação utilizadas para agropecuária, além de presença de estradas cortando os rios, e mais adiante algumas cercas e poços amazonas no ambiente fluvial. Além disso, pode-se observar a presença de vegetação 
exótica, como alguns coqueiros que foram plantados próximos à margem direita do afluente.

Figura 5. Mapa de uso e ocupação do Trecho 2.

\section{Trecho 2}

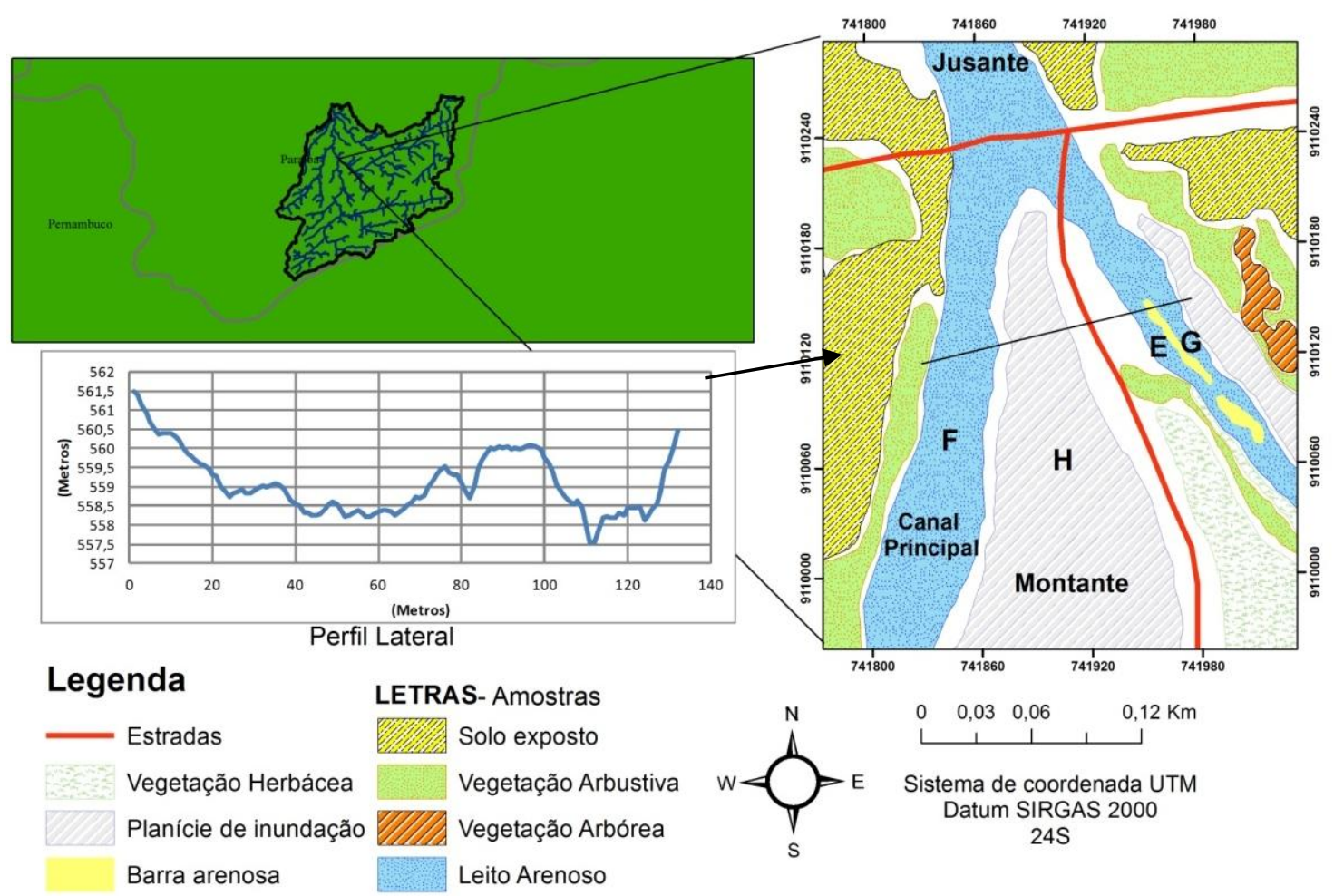

Fonte: Os autores.

Na margem e na encosta direita do riacho Cacimbinha há presença de vegetação arbórea, com cobertura espaçada e predominância de vegetação arbustiva com cobertura intermediária. $\mathrm{Na}$ margem e na encosta esquerda predomina a vegetação herbácea com cobertura intermediária, além da presença de vegetação arbustiva com cobertura espaçada. No leito predomina a presença de vegetação herbácea com cobertura espaçada, também foi possível perceber uma delgada barra arenosa. Já no canal principal, ao lado da margem direita encontra-se uma extensa planície de inundação - que divide os dois canais - onde predomina a vegetação herbácea com cobertura espaçada e na encosta esquerda há predominância de vegetação arbustiva espaçada, ambas as áreas são usadas para agricultura. No leito a vegetação predominante é a herbácea com cobertura espaçada. De modo geral, o trecho 
2 representa uma área de vegetação degradada com pouca cobertura vegetal, podendo gerar influência na estabilidade das margens e favorecer o processo de erosão nas margens.

O canal é de geometria irregular, largura total do vale é de $156 \mathrm{~m}$ e o gradiente da área é de $4 \mathrm{~m} / \mathrm{km}$; e a área de captação atinge uma extensão de 407,3 km², revelando uma grande concentração de fluxo, consequentemente contendo um volume grande de sedimentos. A energia do fluxo nessa área é baixa, conforme os valores do gradiente e a largura do vale, além de se tratar de um trecho que se encontra próximo à foz da bacia.

Em todas as amostras as frações a porcentagem das frações dos sedimentos apresentaram predominância de areia, exceto na amostra $G$, onde a porcentagem de silte é $42 \%$, exatamente igual à porcentagem de areia, pois se trata de uma área rebaixada no leito que possivelmente permanece alagada quando o fluxo do canal cessa. Os dados da amostra da planície de inundação apresentaram grande proporção de sedimentos grosseiros, podendo ser atribuída às possibilidades de modificação da área a partir do uso agrícola.

As amostras do canal correspondente ao riacho Cacimbinha apresentaram proporções maiores de sedimentos finos em relação ao canal correspondente ao riacho do Tigre (tabela 2), já que o rebaixamento do canal permite que a área permaneça alagada, aumentando a probabilidade de deposição de argila e silte. Na planície, por ser uma área muito influenciada pelas atividades humanas, pode ter influenciado nos resultados das análises das amostras, prevalecendo uma proporção maior de cascalho em relação às amostras dos canais. 
Tabela 2. Dados de granulometria e morfoscopia das amostras do trecho 2.

\begin{tabular}{|c|c|c|c|c|}
\hline Amostras & \multicolumn{2}{|c|}{ Classificação dos sedimentos } & \multicolumn{2}{|c|}{ Grau de seleção } \\
\hline$E$ & \multicolumn{2}{|c|}{ Areia fina } & \multicolumn{2}{|c|}{ Muito pobremente selecionado } \\
\hline $\mathrm{F}$ & \multicolumn{2}{|c|}{ Areia fina } & \multicolumn{2}{|c|}{ Muito pobremente selecionado } \\
\hline $\mathrm{G}$ & \multicolumn{2}{|c|}{ Silte grosso } & \multicolumn{2}{|c|}{ Muito pobremente selecionado } \\
\hline $\mathrm{H}$ & \multicolumn{2}{|c|}{ Areia fina } & \multicolumn{2}{|c|}{ Muito pobremente selecionado } \\
\hline \multicolumn{2}{|c|}{ Amostras - Morfoscopia } & Arredondamento & Esfericidade & Brilho \\
\hline \multicolumn{2}{|c|}{$\mathrm{E}$} & Angular & Esférico & Transparente \\
\hline \multicolumn{2}{|c|}{$\mathrm{F}$} & Angular & Esférico & Opaco \\
\hline \multicolumn{2}{|c|}{ G } & Sub Angular & Esférico & Opaco \\
\hline \multicolumn{2}{|c|}{$\mathrm{H}$} & Angular & Esférico & Opaco \\
\hline Amostras & \multicolumn{2}{|c|}{ Diagrama de Shepard } & \multicolumn{2}{|c|}{ Diagrama de Pejrup } \\
\hline $\mathrm{E}$ & \multicolumn{2}{|c|}{ Areia síltica } & \multicolumn{2}{|c|}{ Muito alta } \\
\hline $\mathrm{F}$ & \multicolumn{2}{|c|}{ Areia } & \multicolumn{2}{|c|}{ Alta } \\
\hline $\mathrm{G}$ & \multicolumn{2}{|c|}{ Areia síltica } & \multicolumn{2}{|c|}{ Alta } \\
\hline $\mathrm{H}$ & \multicolumn{2}{|c|}{ Areia síltica } & \multicolumn{2}{|c|}{ Alta } \\
\hline
\end{tabular}

Os trechos 3, 4, 6 e 8 (figura 3) foram agrupados na classe dos depósitos aluviais com alta proporção de sedimentos grosseiros, como cascalho e areia, onde apresentam porcentagens de mais de $90 \%$ da proporção dos sedimentos depositados.

O trecho 3 integra canal principal e está localizado numa zona intermediária na bacia, entre a foz e as áreas de cabeceira, o mapa não será apresentado visto que o mesmo é semelhante a fisionomia do trecho 8 . O canal é arenoso (figura 3), com presença de algumas cacimbas no leito, uma intervenção antrópica bastante comum na região. A vegetação nas encostas tem presença de arbóreas e arbustivas com cobertura espaçada; nas margens e no canal é possível perceber a predominância de herbáceas (cobertura intermediária) e algumas arbustivas (cobertura intermediária), de maneira geral a cobertura vegetal da área é média, assim como a estabilidade à erosão, por se tratar de uma área onde predomina sedimentos grosseiros mais a presença da vegetação faz compensar o nível de degradação.

O gradiente do canal é de $5,7 \mathrm{~m} / \mathrm{km}$, a geometria é irregular, a largura do vale mede $46 \mathrm{~m}$ e a área de captação é de 197,7 km².A energia do fluxo neste trecho é maior em relação aos trechos anteriores já colocados, justamente em consequência dos valores calculados do gradiente e da largura do vale. Já a área de captação é menor em relação aos trechos 1 e 2 , fator que pode ser atribuído à sua localização, já que a drenagem desse trecho não 
recebe fluxo e transporte sedimentar do riacho cacimbinha. Como neste trecho não há divisão de fluxos - devido à ausência de barra arenosa - foi coletada apenas uma amostra, correspondente ao leito do rio, onde será tratada aqui como ponto I (seguindo a sequência das amostras dos trechos anteriores).

A porcentagem dos sedimentos revela a predominância de areia (85\%) enquanto praticamente não há frações de argila. A sedimentação se deu por um fluxo de baixa viscosidade, de acordo com os diagramas (tabela 3). O trecho 4 está localizado em área de cabeceira e corresponde a um canal semiconfinado, onde há extravasamento parcial do fluxo do canal, sendo a margem esquerda confinada - do lado da encosta íngreme - e a margem direita não confinada, com possibilidade de inundação em épocas de cheia (figura 6).

Tabela 3. Dados de granulometria e morfoscopia das amostras do trecho 3.

\begin{tabular}{|c|c|c|c|c|}
\hline Amostras & \multicolumn{2}{|c|}{ Classificação dos sedimentos } & \multicolumn{2}{c|}{ Grau de seleção } \\
\hline I & \multicolumn{2}{|c|}{ Areia grossa } & \multicolumn{2}{c|}{ Pobremente selecionado } \\
\hline Amostras - Morfoscopia & Arredondamento & Esfericidade & Brilho \\
\hline & I & Muito angular & Sub discoidal & Transparente \\
\hline Amostras & \multicolumn{2}{|c|}{ Diagrama de Shepard } & \multicolumn{2}{c|}{ Diagrama de Pejrup } \\
\hline I & \multicolumn{2}{|c|}{ Areia } & \multicolumn{2}{c|}{ Alta } \\
\hline
\end{tabular}

Figura 6. Mapa de uso e ocupação do Trecho 4.

Trecho 4

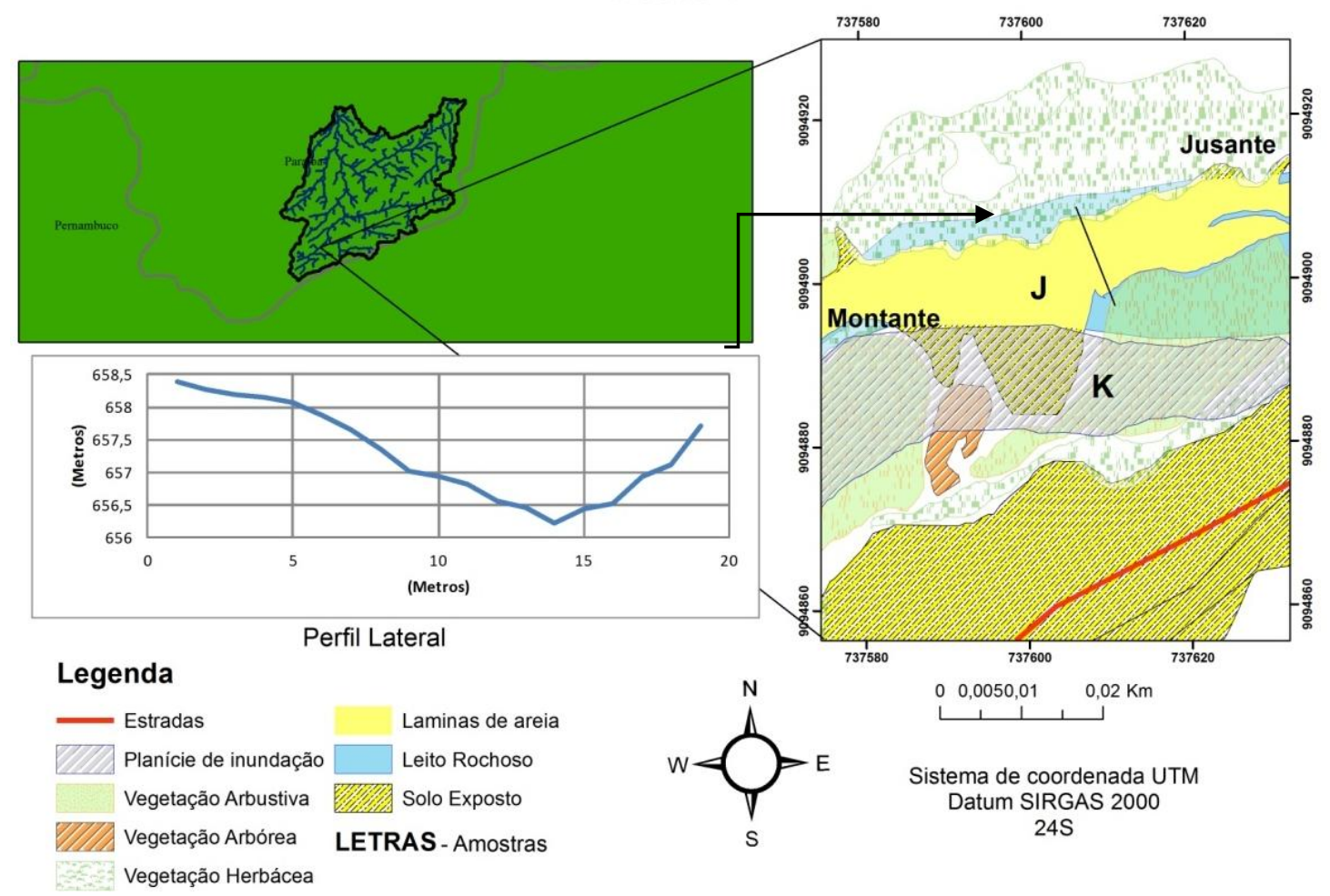

Fonte: Os autores 
Um canal é confinado quando mais de 90\% das margens são confinadas no vale; semi confinado quando $10-90 \%$ das margens são confinadas; e não confinado quando menos de $10 \%$ das margens apresentam incisão no vale (BRIERLEY ET AL, 2002). O leito é rochoso, com trechos com depósitos de areia e alguns blocos que provavelmente são provenientes da encosta. A encosta esquerda é rochosa, havendo uma soleira rochosa próxima ao canal. Ao lado da margem direita há uma planície de inundação e mais adiante é possível perceber uma estrada, algumas casas e terrenos utilizados para agricultura, incluindo na planície de inundação.

A cobertura da vegetação se alterna entre intermediária e densa, com presença de poucas arbóreas na encosta esquerda e muitas herbáceas e arbustivas. As herbáceas se concentram densamente na encosta; As arbustivas predominam na margem direita, no leito e em parte da encosta. $\mathrm{Na}$ parte onde se encontra as casas e as estradas há uma vasta área de solo exposto, podendo ser influenciada pela ação antrópica. De modo geral a cobertura vegetal é bastante concentrada em volta do canal, gerando estabilidade aos processos erosivos.

Após a elaboração e análise do mapeamento - além de dados da estação total - foram obtidas as seguintes informações: A largura do vale é $11 \mathrm{~m}$; o gradiente, cujo cálculo resultou em $9,5 \mathrm{~m} / \mathrm{km}$; a geometria é de um canal assimétrico; e a área de captação hídrica que é de $31,6 \mathrm{~km}^{2}$. Conforme os valores do gradiente e a largura do vale, esse trecho, em comparação com os outros analisados, é o que apresenta maior energia do fluxo no riacho do Tigre, sendo capaz de transportar sedimentos mais grosseiros a jusante. A área de captação é baixa do riacho do Tigre, pois o canal só recebe fluxos provenientes das nascentes da área de cabeceira. 
O processo geral de sedimentação do trecho 4 sofreu influência de um fluxo turbulento, conforme os diagramas de Pejrup (tabela 4). Os dados granulométricos indicam que uma alta variação de vazão provavelmente teria influenciado no processo de sedimentação. A porcentagem de fração de areia é de quase $80 \%$ na amostra $\mathrm{J}$ e $56 \%$ na amostra $\mathrm{K}$. Apesar corresponder à planície de inundação, a amostra $\mathrm{K}$ ainda recebe muito sedimento grosseiro devido à energia do rio, bem como cascalhos removidos das encostas.

Tabela 4. Dados de granulometria e morfoscopia das amostras do trecho 4.

\begin{tabular}{|c|c|c|c|c|}
\hline Amostras & \multicolumn{2}{|c|}{ Classificação dos sedimentos } & \multicolumn{2}{|c|}{ Grau de seleção } \\
\hline $\mathrm{J}$ & \multicolumn{2}{|c|}{ Areia grossa } & \multicolumn{2}{|c|}{ Pobremente selecionado } \\
\hline $\mathrm{K}$ & \multicolumn{2}{|c|}{ Areia média } & \multicolumn{2}{|c|}{ Muito pobremente selecionado } \\
\hline \multicolumn{2}{|c|}{ Amostras - Morfoscopia } & Arredondamento & Esfericidade & Brilho \\
\hline \multicolumn{2}{|c|}{$\mathrm{J}$} & Muito angular & Sub discoidal & Opaco \\
\hline \multicolumn{2}{|c|}{$\mathrm{K}$} & Sub angular & Esférico & Transparente \\
\hline Amostras & \multicolumn{2}{|c|}{ Diagrama de Shepard } & \multicolumn{2}{|c|}{ Diagrama de Pejrup } \\
\hline $\mathrm{J}$ & \multicolumn{2}{|c|}{ Areia } & \multicolumn{2}{|c|}{ Muito alta } \\
\hline $\mathrm{K}$ & \multicolumn{2}{|c|}{ Areia } & \multicolumn{2}{|c|}{ Alta } \\
\hline
\end{tabular}

O trecho 6 corresponde a um canal rochoso, com presença de vários blocos e lâminas de areia, havendo um poço há alguns metros a jusante (figura 7). Os inúmeros blocos causam influência na energia do fluxo, sendo possível observar algumas escavações naturais nas porções de areia a jusante dos blocos maiores. A localização da área fica dentro de uma propriedade privada e o trecho do canal situado no riacho Santa Maria. A encosta direita é rochosa e bastante íngreme, enquanto a encosta esquerda é mais plana, onde na lateral do canal há $22 \mathrm{~m}$ de distância encontra-se uma área destinada à agricultura, além de algumas casas e mais adiante a estrada.

A porcentagem das frações dos grânulos mostrou que há mais de $80 \%$ de fração de areia; as frações de cascalho e silte ficaram abaixo dos $20 \%$; praticamente não há frações de argila. De acordo com o diagrama, um fluxo turbulento influencia nos processos de deposição (tabela 5). De forma geral os resultados indicam a alta energia para a área, estando em consonância com os valores de gradiente. 
Figura 7. Mapa de uso e ocupação do Trecho 6.

Trecho 6

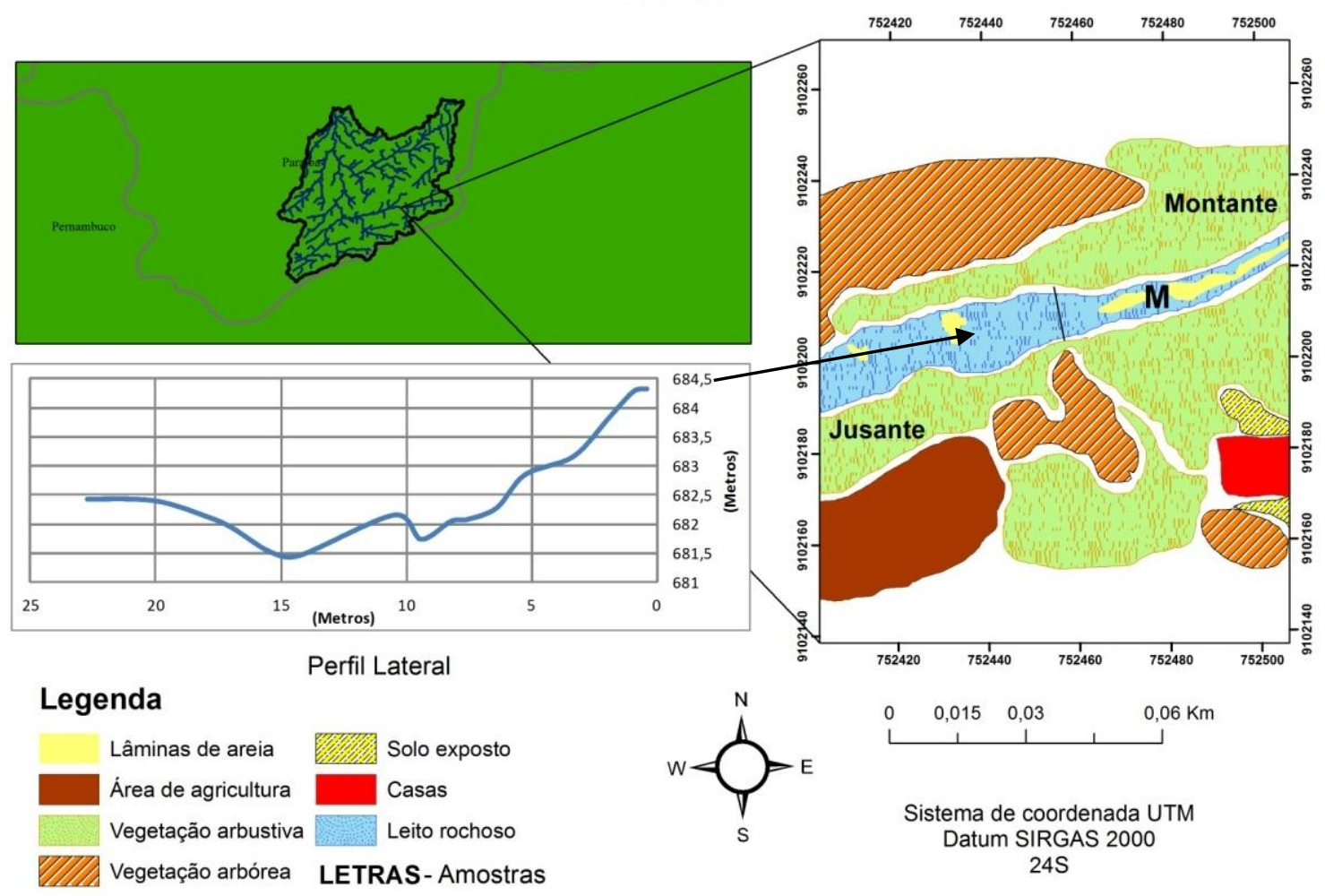

Fonte: Os autores

Tabela 5. Dados de granulometria e morfoscopia das amostras do trecho 6 .

\begin{tabular}{|c|c|c|c|c|}
\hline Amostras & \multicolumn{2}{|c|}{ Classificação dos sedimentos } & \multicolumn{2}{|c|}{ Grau de seleção } \\
\hline$M$ & \multicolumn{2}{|c|}{ Areia grossa } & \multicolumn{2}{|c|}{ Pobremente selecionado } \\
\hline Amostr & scopia & Arredondamento & Esfericidade & Brilho \\
\hline \multicolumn{2}{|c|}{$\mathrm{M}$} & Angular & esférico & орасо \\
\hline Amostras & \multicolumn{2}{|c|}{ Diagrama de Shepard } & \multicolumn{2}{|c|}{ Diagrama de Pejrup } \\
\hline $\mathrm{M}$ & \multicolumn{2}{|c|}{ Areia } & \multicolumn{2}{|c|}{ Muito alta } \\
\hline
\end{tabular}

O leito possui grandes blocos com porções de areia, não havendo cobertura vegetal alguma. Nas encostas a vegetação predominante é a arbustiva, com presença de espécies arbóreas; a cobertura vegetal em volta do canal é densa de forma geral, apresentando alta estabilidade aos processos de degradantes. A largura do vale é de 10,3 m, a geometria do canal é irregular e o gradiente do canal apresentou o valor de $30 \mathrm{~m} / \mathrm{km}$, indicando que a energia do fluxo é muito alta nesse trecho de canal. A área de captação hídrica abrange $36,1 \mathrm{~km}^{2}$, demonstrando ser bem maior em relação ao trecho 5 . 
O trecho 8 está localizado no riacho cacimbinha, posicionado entre o trecho superior e o médio dos canais (figura 8). O leito é arenoso, além disso, há uma barra arenosa que divide o fluxo, apresentando afloramentos rochosos a $35 \mathrm{~m}$ a montante e a $135 \mathrm{~m}$ a jusante da barra. Nas encostas também há afloramentos rochosos, com maior volume em comparação ao leito. A encosta esquerda da frente da barra arenosa apresenta degradação na medida em que o riacho faz a curva. De forma geral a área apresenta pouca intervenção antrópica. A estrada encontra-se a $95 \mathrm{~m}$ do canal. A cobertura vegetal da área é densa de modo geral. Na encosta esquerda predomina vegetação arbórea, incluindo também a presença de vegetação arbustiva. Na encosta direita há poucas arbóreas e predominância de vegetação arbustiva. $\mathrm{Na}$ barra pode-se perceber vegetação arbustiva. A cobertura vegetal fortalece a estabilidade das margens, que já apresenta degradação por apresentar texturas arenosas.

Figura 8: Mapa de uso e ocupação do Trecho 8.

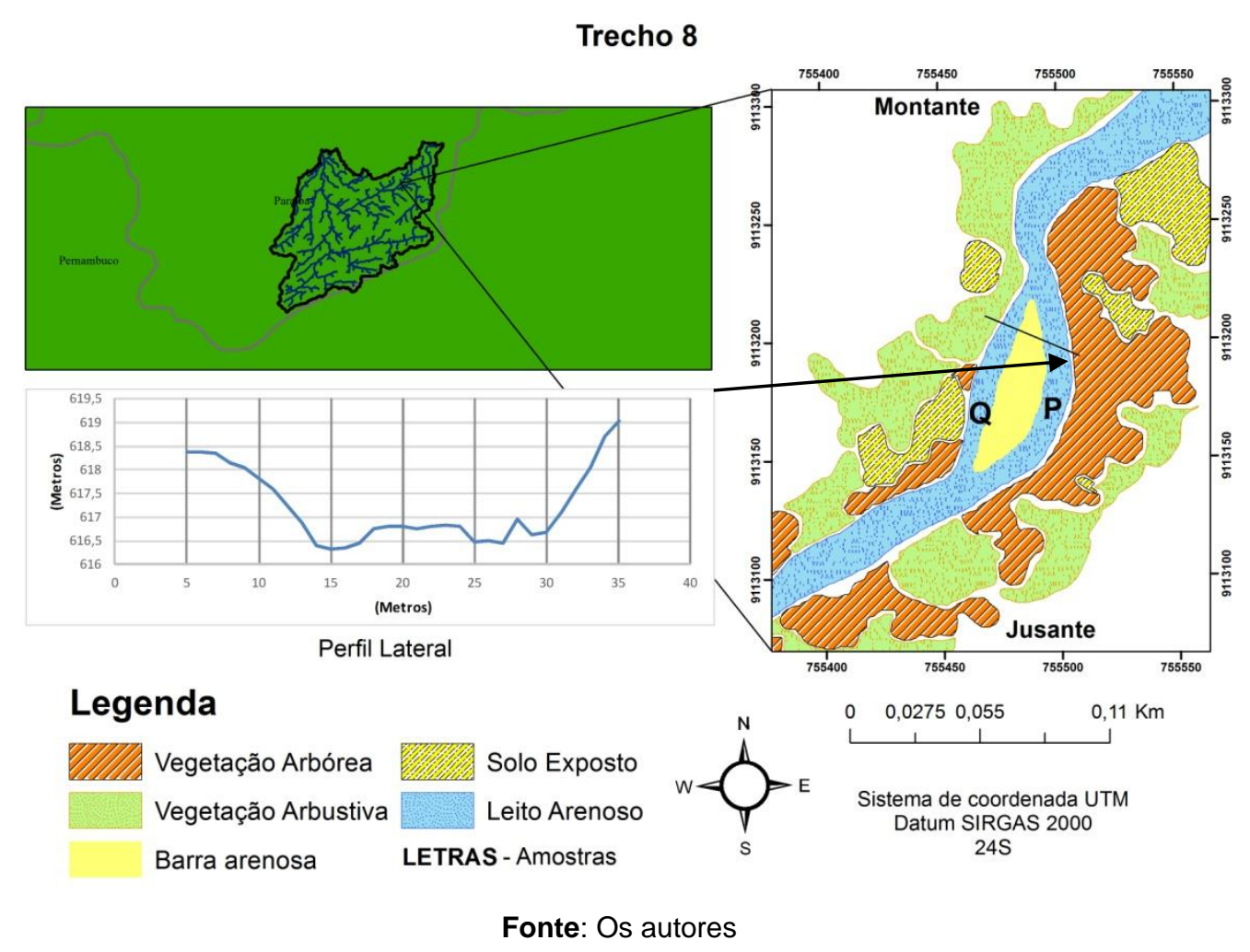


A largura do vale é de 18,2 m, a geometria do canal é irregular e o cálculo do gradiente apresentou valor de $7,3 \mathrm{~m} / \mathrm{km}$, dessa forma a energia do fluxo é maior em relação ao trecho 7. A área de captação também é maior em relação ao trecho 7 , abrangendo $38,5 \mathrm{~km}^{2}$, recebendo uma quantidade maior de volume de fluxo. Os afloramentos rochosos e as soleiras rochosas geram quebra de patamares dentro do canal, fazendo com o que o gradiente aumente.

Foram coletadas duas amostras para o trecho 8, sendo as duas do leito, visto que há uma divisão de fluxo provocada pela presença da barra arenosa. Os dados das análises granulométricas mostram as amostras desse trecho são bem semelhantes. As porcentagens das frações granulométricas apresentaram valores altos para os sedimentos grosseiros como cascalho e areia nas duas amostras, totalizando a soma de $97 \%$ com sobra de $3 \%$ de sedimentos finos na amostra $\mathrm{P}$. Na amostra $\mathrm{Q}$ a porcentagem dos sedimentos grosseiros como cascalho e areia somados totalizam $90 \%$, restando $10 \%$ de silte e areia. Os diagramas de Shepard e Pejrup indicam a predominância de um fluxo turbulento (tabela 6). Apesar do fluxo se dividir em dois canais ele não apresenta variações visíveis para o comportamento do fluxo, conforme as análises sedimentológicas.

Tabela 6. Dados de granulometria e morfoscopia das amostras do trecho 8.

\begin{tabular}{|c|c|c|c|c|}
\hline Amostras & \multicolumn{2}{|c|}{ Classificação dos sedimentos } & \multicolumn{2}{|c|}{ Grau de seleção } \\
\hline $\mathrm{P}$ & \multicolumn{2}{|c|}{ Areia muito grossa } & \multicolumn{2}{|c|}{ Moderadamente selecionado } \\
\hline Q & \multicolumn{2}{|c|}{ Areia grossa } & \multicolumn{2}{|c|}{ Pobremente selecionado } \\
\hline \multicolumn{2}{|c|}{ Amostras - Morfoscopia } & Arredondamento & Esfericidade & Brilho \\
\hline \multicolumn{2}{|c|}{$\mathrm{P}$} & Muito angular & Esférico & Opaco \\
\hline \multicolumn{2}{|c|}{$Q$} & Muito angular & Esférico & Opaco \\
\hline Amostras & \multicolumn{2}{|c|}{ Diagrama de Shepard } & \multicolumn{2}{|c|}{ Diagrama de Pejrup } \\
\hline $\mathrm{P}$ & \multicolumn{2}{|c|}{ Areia } & \multicolumn{2}{|c|}{ Alta } \\
\hline $\mathrm{Q}$ & \multicolumn{2}{|c|}{ Areia } & \multicolumn{2}{|c|}{ Muito alta } \\
\hline
\end{tabular}

Os trechos 5 e 7 se inserem na classe dos depósitos aluviais de vale preenchido, contendo também altas proporções de argila e silte. $\mathrm{O}$ trecho 5 está localizado nas mediações do riacho Santa Maria e corresponde a uma área de vale preenchido entre encostas íngremes, há mais de $1000 \mathrm{~m}$ de altitude (figura 9). $\mathrm{O}$ trecho se encontra muito próximo à nascente do riacho 
que drena para o rio Santa Maria. No topo da encosta direita há $350 \mathrm{~m}$ do vale algumas casas, uma estrada áreas reservadas para a agricultura e pecuária, sendo o fundo vale também utilizado para pastagem do gado. Não há incisão de um canal bem definido no vale, revelando a geometria de um canal com descontinuidade, possivelmente pela baixa área de captação. O leito é arenoso com presença de vegetação herbácea densa. A cobertura vegetal das encostas é densa, com presença de vegetação arbustiva e predominâncias de vegetação arbórea. De forma geral é um trecho com cobertura vegetal densa e alta estabilidade aos processos erosivos.

O gradiente da área é de $5,7 \mathrm{~m} / \mathrm{km}$, a geometria é de um canal não confinado e a largura do vale é $59,8 \mathrm{~m}$, dessa forma a energia do fluxo é mediana em relação aos valores aqui já apresentados em outros trechos da bacia. A área de captação é relativamente baixa, abrangendo $2,9 \mathrm{~km}^{2}$, isso porque este trecho se encontra bem próximo à nascente do riacho, não havendo recebimento de fluxos de outros canais. Assim, mesmo apresentando um gradiente mediano a acumulação de fluxos é muito baixa, e em conjunto com o vale largo, faz com que não tenha energia suficiente para gerar uma incisão vertical, e consequentemente a formação de um canal escavado.

Para este trecho foi coletada apenas uma amostra, correspondente ao leito do vale, visto que essa área não apresenta variedades de unidades geomórficas. Sendo assim, a amostra coletada foi classificada como L, seguindo a mesma sequência das amostras dos trechos anteriores. 
Figura 9: Mapa de uso e ocupação do Trecho 5.

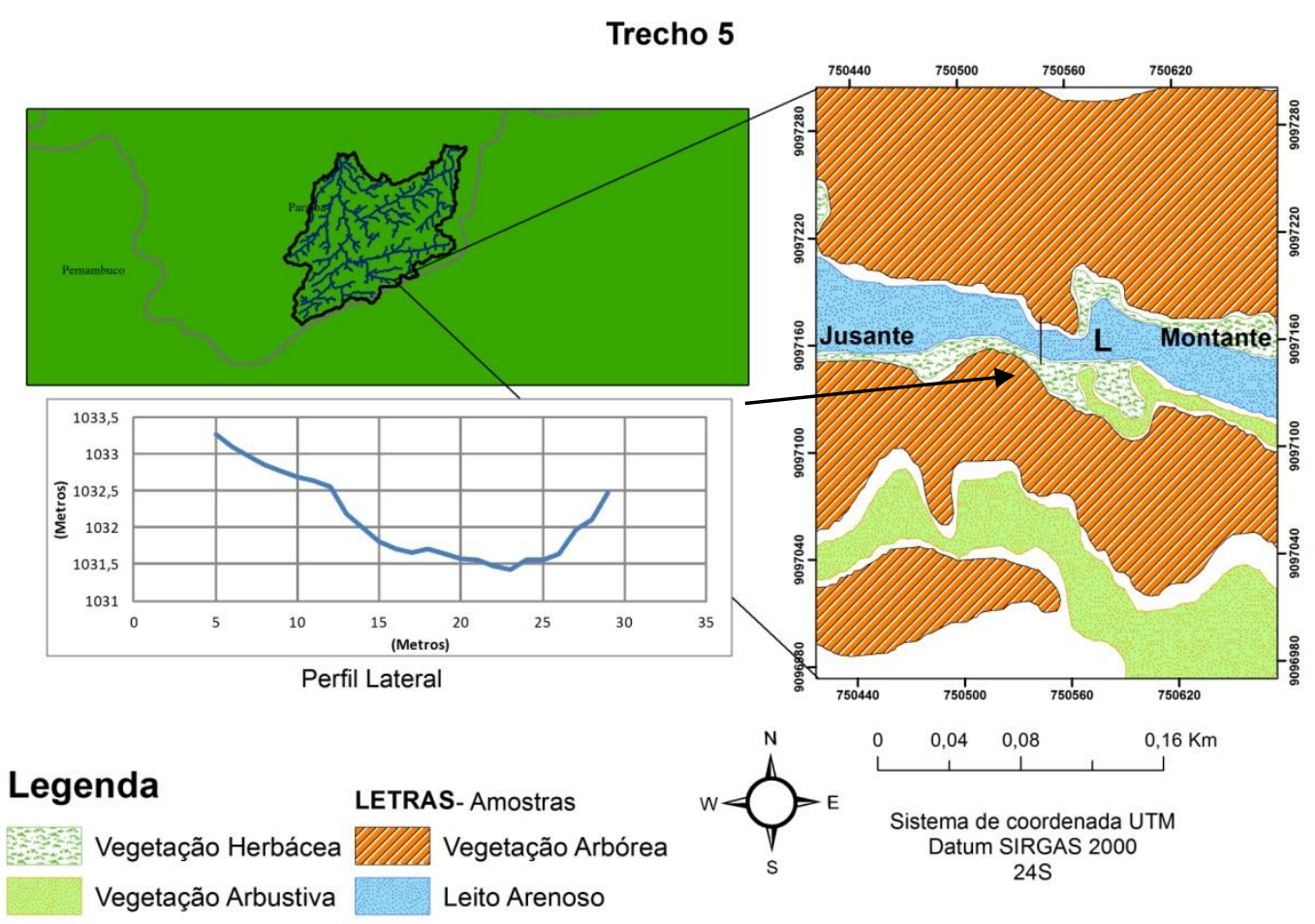

Fonte: Os autores

Os dados revelam a influência da turbulência do fluxo na dinâmica processual da sedimentação (tabela 7). As porcentagens das frações granulométricas apontam as frações de areia como majoritárias, chegando perto dos $60 \%$, o restante das frações apresenta porcentagem mais equilibradas, sendo a de silte com um pouco mais de $20 \%$ e as de argila e cascalho abaixo dos $20 \%$. O resultado de valores altos para sedimentos finos é mais um indicador de que o fluxo da área não tem tanta energia.

Tabela 7. Dados de granulometria e morfoscopia das amostras do trecho 5.

\begin{tabular}{|c|c|c|c|c|}
\hline Amostras & \multicolumn{2}{|c|}{ Classificação dos sedimentos } & \multicolumn{2}{|c|}{ Grau de seleção } \\
\hline $\mathrm{L}$ & \multicolumn{2}{|c|}{ Areia muito fina } & \multicolumn{2}{|c|}{ Muito pobremente selecionado } \\
\hline \multicolumn{2}{|c|}{ Amostras - Morfoscopia } & Arredondamento & Esfericidade & Brilho \\
\hline 1 & & Angular & Sub Discoidal & Opaco \\
\hline Amostras & \multicolumn{2}{|c|}{ Diagrama de Shepard } & \multicolumn{2}{|c|}{ Diagrama de Pejrup } \\
\hline $\mathrm{L}$ & \multicolumn{2}{|c|}{ Areia síltica } & \multicolumn{2}{|c|}{ Alta } \\
\hline
\end{tabular}

O trecho 7 representa uma área arenosa de vale preenchido, localizado em um dos afluentes da drenagem do rio Cacimbinha, contudo nesse caso há influência direta na presença de um barramento a jusante do trecho, 
representando assim um depósito sedimentar com gênese/potencialização na intervenção antrópica (figura 10). O vale não apresenta uma incisão de canal definida, contendo poucas incisões onde a textura é mais fina, portanto, sua geometria é de um vale não confinado com incisões de canais descontínuos; a encosta esquerda é íngreme e contém alguns blocos rochosos e matacões; na encosta direita a inclinação é mais suave, apresentando ao seu lado uma estrada. Há aproximadamente $200 \mathrm{~m}$ a montante algumas cercas cortando o canal, sendo a área utilizada para pastagem animal.

Figura 10: Mapa de uso e ocupação do Trecho 7.

\section{Trecho 7}

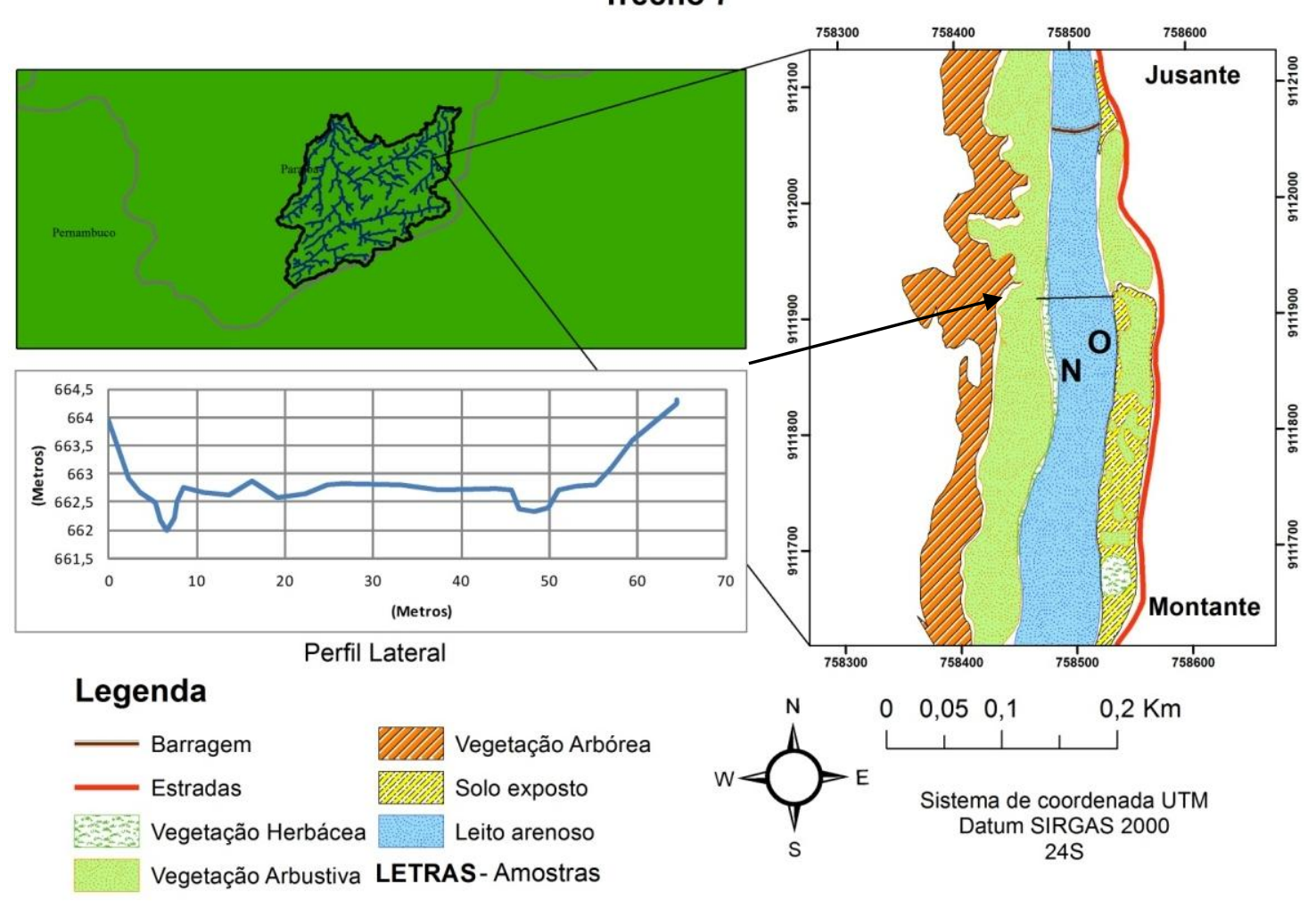

Fonte: Os autores

A área em si é sofre influência das intervenções antrópicas, havendo uma barragem de aproximadamente $8 \mathrm{~m}$ de altura, tendo sido construída há dez anos, e pelo registro dos moradores antes da barragem o leito era predominantemente rochoso. Após a construção da barragem o leito passou a ser totalmente arenoso no trecho a montante da barragem; a jusante, a pouca 
distância após a barragem o leito ainda é arenoso, mas apresenta alguns blocos rochosos.

A cobertura vegetal na encosta esquerda é densa, composta de vegetação arbórea e vegetação arbustiva; no leito há presença de vegetação herbácea com cobertura vegetal intermediária; na encosta direita prevalece a vegetação arbustiva com cobertura espaçada, além da presença de solo exposto já em contato com a estrada.

O gradiente da área é de $7 \mathrm{~m} / \mathrm{km}$ e a largura do vale apresentou medida de 62,5 m, demonstrando ser um canal que recebe um fluxo com energia média, contudo a presença do barramento impede a remoção dos sedimentos, elevando artificialmente o nível de base local, o que também pode ser notada pela ausência de uma incisão bem definida do canal, típico de área de vale preenchido. A área de captação hídrica abrange $25,9 \mathrm{~km}^{2}$, já que o trecho está localizado numa área próxima de cabeceira. Para este trecho foram coletadas duas amostras do leito do canal. A amostra $\mathrm{N}$ corresponde ao seguimento plano do canal em uma incisão muito pequena. A amostra $\mathrm{O}$ foi coletada de uma incisão mais rebaixada do canal, próximo à margem direita e aparentemente de textura mais fina.

Os dados de granulometria confirmam que as amostras apresentam características distintas uma da outra (tabela 8). A porcentagem das frações granulométricas é de $95 \%$ de areia na amostra $\mathrm{N}$, predominando em quase toda a amostra; na amostra $\mathrm{O}$ a proporção dos sedimentos é mais equilibrada quanto à amostra $\mathrm{N}$, com $42 \%$ de silte, 39\% de areia, 14\% de argila e 5\% de cascalho. De maneira geral a amostra $\mathrm{N}$ apresentou resultados que indica mais facilidade no transporte de sedimentos finos, ao contrário da amostra $\mathrm{O}$, podendo ser atribuído ao maior rebaixamento propiciando o alagamento ou poças quando o fluxo se torna estático. 
Tabela 8. Dados de granulometria e morfoscopia das amostras do trecho 7.

\begin{tabular}{|c|c|c|c|c|}
\hline Amostras & \multicolumn{2}{|c|}{ Classificação dos sedimentos } & \multicolumn{2}{|c|}{ Grau de seleção } \\
\hline $\mathrm{N}$ & \multicolumn{2}{|c|}{ Areia grossa } & \multicolumn{2}{|c|}{ Moderadamente selecionado } \\
\hline $\mathrm{O}$ & \multicolumn{2}{|c|}{ Silte grosso } & \multicolumn{2}{|c|}{ Muito pobremente selecionado } \\
\hline \multicolumn{2}{|c|}{ Amostras - Morfoscopia } & Arredondamento & Esfericidade & Brilho \\
\hline \multicolumn{2}{|c|}{$\mathrm{N}$} & Sub angular & Sub Discoidal & Opaco \\
\hline \multicolumn{2}{|c|}{$\mathrm{O}$} & Sub angular & Esférico & Opaco \\
\hline Amostras & \multicolumn{2}{|c|}{ Diagrama de Shepard } & \multicolumn{2}{|c|}{ Diagrama de Pejrup } \\
\hline $\mathrm{N}$ & \multicolumn{2}{|c|}{ Areia } & \multicolumn{2}{|c|}{ Alta } \\
\hline $\mathrm{O}$ & \multicolumn{2}{|c|}{ Areia síltica } & \multicolumn{2}{|c|}{ Alta } \\
\hline
\end{tabular}

De maneira geral nos depósitos aluviais do riacho do Tigre a proporção de cascalho e areia é maior na cabeceira trecho 4, apresentando redução dos valores a jusante. Já em relação à proporção de argila e silte ocorre o inverso, os valores são crescentes a montante, sendo o trecho 2 o que apresenta maior valor. Esses valores refletem a localização de cada trecho na perspectiva do continuum fluvial, a quantidade maior de argila e silte nos trechos 1 e 2 revelam as características de um fluxo com baixa energia comum de uma área com gradiente baixo, na qual esse fluxo não possui capacidade de transportar sedimentos mais grosseiros. Nos trechos 3 e 4, o gradiente é maior e o fluxo possui maior energia em relação aos trechos 1 e 2, dessa forma os fluxos os sedimentos mais finos como areia e silte são transportados com mais facilidade, explicando a proporção maior em relação aos trechos 1 e 2 de sedimentos grosseiros como cascalho e areia em seus depósitos aluviais.

Já os depósitos aluviais dos dois trechos analisados nas mediações do riacho Santa Maria apresentaram características distintas. Os depósitos aluviais do trecho 5 apresenta grau de seleção mais pobre que o trecho 6, além de conter maiores proporções de argila e silte, totalizando $36 \%$ para os sedimentos finos, enquanto que a soma das porcentagens de cascalho e areia resultam em 64\%, com predominância das frações de areia. A porcentagem das frações granulométricas no trecho 6 resultam em 96\% para os sedimentos grosseiros, com predominância das frações de areia em 86\% e 10\% de cascalhos, dessa forma nesse trecho também há uma proporção maior de cascalho em relação ao trecho 5. Sendo assim, restaram 4\% de sedimentos finos, sendo que desses $4 \%$ apenas $1 \%$ corresponde às frações de argila e os 
outros 3\% para as frações de silte. Essas diferenças se dão pelas características físicas de cada trecho, na qual influência nos processos de deposição; o trecho 5 é uma área arenosa de vale preenchido, sem uma incisão bem definida do canal, com baixa declividade e com pequena área de captação, dessa forma a energia do fluxo é baixa, permitindo apenas o transporte dos sedimentos mais finos como silte e argila; já no trecho 6 a declividade é bastante alta, o canal é rochoso, estreito, com presença de lâminas de areia, logo a energia do fluxo é bastante alta, além disso a presença dos blocos rochosos aumentam a turbulência do fluxo, sendo capaz de transportar sedimentos mais grosseiros, enquanto que os sedimentos finos são transportados com extrema facilidade, fazendo com que quase não haja frações de silte e argila. De maneira geral o trecho 5 representa os vales/canais presente nos topos planos; o trecho representa os canais encaixados em falhas.

Observando de forma abrangente os depósitos aluviais trabalhados nas mediações do riacho Cacimbinha, as frações de areia predominam nos trechos 7 e 8 , contendo quase o mesmo valor de porcentagem, sendo $67 \%$ para o trecho 7 e 68\% para o trecho 8. No entanto a proporção de cascalho é consideravelmente maior no trecho 8 , ultrapassando os $20 \%$, enquanto que no trecho 7 é de 3,7 \%. Desse modo, a proporção de sedimentos finos como argila e silte são maiores no trecho 7, chegando perto dos $30 \%$; no trecho 8 a proporção da soma de argila e silte totalizam quase $7 \%$. Como a energia do fluxo do trecho 8 é bem maior em relação ao trecho 7, os sedimentos mais finos são transportados com mais facilidade, restando um volume menor dos mesmos. Os depósitos aluviais dos trechos 7 sofreram influência de um gradiente mais baixo, além de ser uma área de vale preenchido, fazendo com que o fluxo apresente uma baixa energia, sendo incapaz de transportar sedimentos mais grosseiros, depositando proporções maiores das frações de silte e argila.

Todos os trechos apresentaram hidrodinâmica alta ou muito alta, característica comum de ambientes fluviais semiáridos. Os dados de 
morfoscopia revelam que os grãos são mais arredondados e esféricos na medida em que o seguimento do rio se aproxima a jusante. Com base nos trechos analisados, a área de captação demonstrou ser maior a jusante, propiciando maiores recargas nos aquíferos aluviais situados próximo à foz. O processo inverso ocorre referente à energia do fluxo, apresentando potencial maior a montante, na medida em que o seguimento do rio se aproxima das áreas de cabeceira. Em todos os trechos foram encontradas evidências de influência das atividades humanas nos ambientes fluviais, ocorrendo nos trechos do riacho do tigre com mais intensidade e no trecho 8 com intensidade menor, incluindo o trecho 7 no qual a interferência antrópica, barramento do canal, controla diretamente o processo de sedimentação.

\section{Considerações finais}

Analisando a bacia de forma geral, os sítios de deposição estão concentrados nos ambientes de baixo gradiente, na qual foram submetidos ao transporte fluvial de segmentos com altitude mais elevadas, na perspectiva da posição do canal no perfil longitudinal. As características geológicas, biogeográficas, topográficas, climáticas e as intervenções antrópicas têm controlado a diversidade fluvial na bacia riacho do Tigre, gerando influência no processo de deposição dos trechos analisados.

O fluxo dos rios semiáridos apresenta comportamento de vazão diferente dos ambientes fluviais úmidos, aumentando e diminuindo a vazão de maneira extremamente rápida, sendo caracterizado por uma hidrodinâmica alta, gerando assim uma grande variação nos depósitos aluviais, controlando o baixo grau de seleção dos mesmos. A variação dos depósitos aluviais propicia a formação de aquíferos aluviais com características diversas, podendo causar influência nos processos de infiltração, permeabilidade e recarga dos aquíferos aluviais. A caracterização sedimentológica pode auxiliar na compreensão e gestão dos aquíferos aluviais, gerando informações sobre sua capacidade do volume de água e 
permeabilidade, assim como a coesão e capacidade erosiva dos depósitos aluviais.

De forma geral, apesar da predominância de areia em todos os trechos analisados, as análises sedimentológicas apresentaram maiores proporções de sedimentos finos (silte e argila) nos ambientes de baixo gradiente em comparação aos demais trechos, devido localização próxima à foz da bacia. Os sedimentos grosseiros como cascalho e areia apresentaram maiores proporções nas áreas com gradiente mais elevado - com estimativa de mais de 90\% - em localizações próximas às áreas de cabeceira.

\section{Referências}

ALBUQUERQUE, C.; MONTENEGRO, S.; MONTENEGRO, A.; JÚNIOR, R.. Recarga de aquífero aluvial sob uso agrícola. Águas Subterrâneas, v.29, n.1, p.60-71, 2015.

BIGARELLA, J. J.; SUGUIO, K.; BECKER, R. D. Ambiente fluvial: ambientes de sedimentação, sua interpretação e importância. 1. ed. Curitiba: Editora da Universidade Federal do Paraná. Associação de Defesa e Educação Ambiental, 1979.

BRIERLEY et al. Application of the river styles framework as a basic for river magenement in new south wales, Australia. Appied Geography, n.22, p.91-122, 2002.

CAVAlCANTE, A. A.; CUNHA, S. B. Morfodinâmica Fluvial em Áreas Semiáridas: Discutindo o Vale do Rio Jaguaribe - CE - Brasil. Revista Brasileira de Geomorfologia, v.13, n.1, p. 39-49, 2012. https://doi.org/10.20502/rbg.v13i1.340

CPRM. Projeto cadastro de fontes de abastecimento por água subterrânea. Diagnóstico do município de São João do Tigre, Estado da Paraíba. Recife: CPRM/PRODEEM, 2005.

CORREAA, A; TAVARES, B; MONTEIRO, K; CAVALCANTI, L; LIRA, D. Megageomorfologia e morfoestrutura do Planalto da Borborema. Revista do Instituto Geológico, v.31, n. 1/2, p.35-52, 2010.

FERREIRA, I.; SOUZA, L.; RODRIGUES, S. Estudos geomorfológicos em areas amostrais da bacia do rio Araguari - MG: Destaque para a importância da cartografia geomorfológica. Espaço \& Geografia, v.10, n.1, p.143-171, 2007.

FOLK, R. L. \& WARD, W. Brazos River bar: a study in the significance of grain size parameters. Journal of Sedimentary Research, v.27, p.3-26, 1957. https://doi.org/10.1306/74D70646-2B21-11D7-8648000102C1865D 
FONTES JÚNIOR, R.; MONTENEGRO, A.; MONTENEGRO, S.; SANTOS, T. Estabilidade temporal da potenciometria e da salinidade em vale aluvial no semiárido de Pernambuco.Revista Brasileira de Engenharia Agrícola e Ambiental, v.16, n.11, p.1188-1197, 2012. https://doi.org/10.1590/S1415-43662012001100007

FRYIRS, K. A. and BRIERLEY, G. J. Geomorphic Analysis of River Systems: An Approach to Reading the Landscape, John Wiley \& Sons, Ltd, Chichester, UK, 2012.

GALE, S. J. \& HOARE, P. G. Quaternary sediments: petrographic methods for the study of ulithified rocks. Londres: Bethaven Press, 1991. https://doi.org/10.1002/9781118305454

GALVÍNCIO, J.; SÁ, I.; MOURA, M.; RIBEIRO, J. Determinação das características físicas, climáticas e das paisagem da bacia hidrográfica do rio Brígida com o auxílio de técnicas de geoprocessamento e sensoriamento remote. Revista de Geografia, v.24, n.2, p.83-96, 2007. GRAF et al. Sedimentation and sustainability of western American reservoirs. Water Resources research, v.46, w.12345, p.1-13, 2010.

IBGE - Instituto Brasileiro de Geografia e Estatística. Cidades / Paraíba. Disponível em:<http://cidades.ibge.gov.br/xtras/perfil.php?lang=\&codmun=251410\&search=\|linfogr\%E1fico s:-informa\%E7\%F5es-completas>. Acesso em: 28 mar. 2016.

LOVE et al. A water balance modeling approach to optimising the use of water resources in ephemeral sand rivers.River Research and applications, v.27, p.908-925, 2011.

MARQUES, A.; GALO, M. Escala Geográfica e Escala Cartográfica: Distinção Necessária. Boletim de Geografia, v.26/27, n.1, p.47-55, 2008.

MEDEIROS, V.; MOREIRA, L.; RIGHETTO, A. Análise do efeito da variabilidade espacial da precipitação na modelagem do escoamento numa bacia experimental no semiárido nordestino. Revista Brasileira de recursos hídricos, v.12, n.3, p. 129-139, 2007.

PEJRUP, M. The triangular diagram used for classification of estuarine sediments: a new approach. In: BOER, P. L.; VAN GELDER, A.; NIO, D. D. (eds.). Tide-Influenced Sedimentary Environments and Facies. Reidel: Dordrecht, p.289-300, 1988. https://doi.org/10.1007/978-94-015-7762-5 21

PIRES, J. S. R.; SANTOS, J. E.; DEL PRETTE, M. E. A utilização do conceito de Bacia Hidrográfica para a conservação dos recursos naturais. In: SCHIAVETTI, A.; CAMARGO, A. F. M. Conceitos de bacias hidrográficas: teorias e aplicações. Ilhéus: Editus, 2008. p. $17-35$

SÁ, J. U.; DINIZ, J. A. O. Aproveitamento das aluviões do semiárido do nordeste. In: XVII Congresso Brasileiro de águas subterrâneas e XVII Encontro Nacional de perfuradores de poços. Bonito: 2012. 
SALES, V. C. Geografia, Sistemas e Análise Ambiental: Abordagem Crítica. GEOUSP Espaço e Tempo, São Paulo, n.16, p.125-141, 2004.

SANTOS, M. V. C.; FREIRE, C. C.; SOUZA, V. C. B. Comportamento do fluxo subterrâneo em um aqǘfero aluvial no semi-árido alagoano. In: XVIII Simpósio Brasileiro de Recursos Hídricos. Campo Grande: 2009.

SCHUSTER et al. Uma investigação dos efeitos hidráulicos de barragens subterrâneas em um aquífero aluvial na região semiárida da Paraíba. Revista Brasileira de Recursos Hídricos, v.9, n.3, p.55-69, 2004.

SHEPARD, F. P. Nomenclaturebasedonsand-silt-clayratios. Journal of Sedimentary Petrology, v.24, p.151-158, 1954.

SILVA, K.; OLIVEIRA, D. Mapeamento de Anomalias de Drenagem: indícios de controles litológico e estrutural na bacia hidrográfica do Cotia, em Cotia - SP, Brasil. Quartenary and Environmental Geosciences, v.1, n.2, p.76-83, 2009.

SOUZA, J. O. P. Dos Sistemas Ambientais ao Sistema Fluvial - Uma Revisão de Conceitos. Revista Caminhos da Geografia, v.14. n.46. p.224-233, 2013.

SOUZA, J. O. P.; ALMEIDA, J. D.M. Processos Fluviais em Terras Secas: uma revisão. Revista OKARA: Geografia em debate, v.9, n.1, p.108-122, 2015.

SOUZA, J.O.P.; CORRÊA, A.C.B. Sistema Fluvial e Planejamento Local no Semiárido. Mercartor, v.11, n.24, p.148-168, 2012. https://doi.org/10.4215/RM2012.1124.0010

TRENTIN, R; SANTOS, L; ROBAINA, L. Compartimentação geomorfológica da bacia hidrográfica do rio Itu - Oeste do Rio Grande do Sul - Brasil. Sociedade e Natureza, v.24, n.1, p.127-142, 2012. https://doi.org/10.1590/S1982-45132012000100011

TROPPMAIR, H.; GALINA, M. Geossistemas. Mercator - Revista de Geografia UFC, v.5, n.10, p.79-89, 2006.

TUCKER, M. Techniques in Sedimentology. London: Blackwell, 1995.

VICENTE, L. E. ; PEREZ FILHO, A. Abordagem Sistêmica e Geografia. Revista Geografia - Rio Claro, v. 28, n. 3, p. 323-344, 2003.

Data de submissão: 20/10/2016. Data de aceite: 22/06/2017. 